\title{
The pattern of upbringing of middle to lower economic families in urban communities
}

\author{
Diva Oktaviana \\ Department of Anthropology \\ Faculty of Social and Political Science, Universitas Airlangga \\ Address: Jalan Dharmawangsa Dalam, Surabaya 60286 \\ E-mail: diva.oktaviana-2017@fisip.unair.ac.id
}

\begin{abstract}
The purpose of writing this article is to examine the way parenting can influence the growth of attitudes and character in children from families in lower middle economic classes. By studying the parenting, the most appropriate parenting for children's growth and development. The study was conducted on the social figures around children, especially parents and teachers who can understand every pattern of development that occurs in children in a city. This research utilized in-depth interviews and observation methods in order to identify the meeting point that the best parenting pattern is democratic parenting. Therefore, the inculcation of attitudes towards children from an early age must indeed be carried out to support the implementation of democratic parenting. Family and school are the social institutions that are interlocking and have a reciprocal relationship since both hold an important role for the growth and development of children. Having a synergistic relationship and becoming the social control for children are the essential key in improving the children's quality in the future. Economic limitations are not an obstacle to the fulfillment of the social role held by parents and schools. Precisely with this awareness, it is expected that families can become more aware of the impacts resulting from parenting mistakes. Children who will become the future of the family will be saved. Social mobility is also highly likely to occur when parenting is properly implemented.
\end{abstract}

Keywords: parenting, family, child development

\section{Introduction}

Children are a gift that the Creator presents to His servants. All children are born with different parents and family backgrounds. This is also supported by parenting theory from Baumrind (Mirsanti \& Warsiki 2010) which uses a typo-logical approach and the existence of socialist practices in a family. Child's growth and development is greatly influenced by the things that occur in the surrounding environment. It starts from the smallest part, which is family. Family, however, actually brings a very big influence. As a sub-organization that is very vital in social life, families should be able to produce quality new members of society. Families that should be the first school for every child are often overlooked and this opportunity is not utilized properly even though family should have been the place where the whole knowledge, cognitive development, and even the child's personality will be formed. Family cannot escape from its responsibilities. Children are the duplicate product of their parents. When they are still very young, children will be looking for models to be used as their examples for the period of growth and development. If children fail to find the appropriate model to imitate in their growth and development, it is possible for the children to have a variety of significant impacts on the development of their lives. Psychologically, children are teaching materials that have their own space to undergo growth and development. That is exactly the reason that parenting becomes a very important thing to discuss. High level of children delinquency becomes the community problems that arise and do not go away.

The neighborhood around children also becomes the factor that supports the psychological development of children as the statement in the tabula rasa theory by John Locke (Haryono 2012) which suggests that environment becomes a vital thing and is very influential on one's personality. Environment can contribute a lot of things. A good environment will provide a good influence on children so that the psychological quality of children increases and is able to shape the children into 
Oktaviana: The pattern of upbringing of middle to lower economic families in urban communities

individuals with good personalities. Conversely, a bad environment will provide bad impacts on children. Quality character development will decline or even be unable to implement. Children with poor psychological development will be rejected or excluded from their environment.

Lower-class environment refers to people the life of whom is below the poverty line. The lower classes are economically considered to be financially incapable to meet their basic needs such as the need for clothing, food, and housing. This environment will give its own color to the psychological development of children who live in the lower middle class. It can be observed that the lower classes are spread in various places. From the suburbs to the center or the heart of the city, they are still easy to encounter, especially in metropolitan cities that have a high level of social gap. The high level of parenting mistakes in the lower middle class has broad and even overall impacts (Bahruddin 2013).

\section{Attitude inculcation}

For the period of human growth and development, children stage is quite crucial because at that stage, children begin to learn to recognize their environment and learn about life. The inculcation of attitude is actually carried out to provide understanding of attitudes to children. What attitudes and behaviors are good for the environment so that later, the children will grow as a person who has exemplary behaviors and attitudes. Fundamentally, attitude and behavior are two different but interrelated things.

Campbell (1950) in Notoadmodjo (2003: 29) in Rahmayanti (2011) states that attitude can be interpreted as a response that runs constantly or consistently on an object in the social environment. Meanwhile, according to the concept of attitude proposed by Eagle and Chaiken (1993) in A. Wawan and Dewi M. (2010) in Rahmayanti (2011), attitude can be placed as a reflection of the attitude object which is then expressed through cognitive, affective and behavioral process. Therefore, the difference in meaning between attitude and behavior can be understood. Attitudes lead to the soul, the internal part which will then be manifested through behavior. Hence, behavior is the reflection of attitude in the form of actions.

The characteristics of attitude according to Heri Purwanto (1998) in Notoadmodjo (2003) in Rahmayanti (2011) mentioned that attitude is not something that is carried since birth, but it can be obtained and formed by studying and instilling it in the object himself. Children who are analogized to a sheet of blank paper must be filled with appropriate ink to look beautiful and in accordance with their functionalities. The analogy is valid because early attitude inculcation is indeed very necessary, as it is known that the attitude is not in accordance with one's nature since birth. Therefore, this attitude formation will have a very big impact on children's future lives. Attitudes can vary on the basis of circumstances and certain conditions that exist around the attitude object. The changes that emerge and occur can be generated by several things, one of which is the environment. When the environment becomes a causative factor, then the environment with certain social patterns must be adjusted to the children. The environment will shape the children's attitude in accordance with the social patterns that are intertwined in it. Changes that are not in harmony with the prevailing behavior and norms will cause individuals to be rejected or excluded from their environment because they are considered different. Attitude will not stand alone, so it is very possible that attitude has a certain relationship with an object. The attitude object is a certain thing but it also does not rule out the possibility that the attitude object becomes part of that particular thing. Attitude has aspects of motivation and aspects of feeling.

Functionally, attitude definitely has certain roles that was described by Katz (1964) in Wawan and Dewi (2010) in Rahmayanti (2011), which are:

a. Instrumental function. This function deals with achieving an objective. If the attitude object can help achieve an objective, then the society will be able to accept and be positive about it. On the contrary, however, if the attitude object hinders the achievement of an objective, then the society will be negative to the attitude object. 
b. Ego defense function. This function appears or is carried out by an object when it is in a pressured situation.

c. Value expressive function. By taking a certain attitude, then an individual is trying to express a value. He is trying to show the environment the value system that exists in the individual.

d. Knowledge function. If someone has a certain attitude towards an object, then it will show his knowledge about the attitude object in question.

Observing from the things that have been described above, it is an obvious that attitude becomes something that is very vital for an individual. Individuals who become the attitude object have their own rights and abilities to determine attitudes that exist in themselves, regardless of the emergence of other factors that influence the growth of attitudes like internal and external factors.

\section{Parenting}

Family is the first place where children stand in the real world. In addition to having the main function as explained by Haryono (2012), which is to obtain and expect assistance and protection between the family members, family guarantees that each member feels safe in the group. The second function is to obtain parenting and education that can take the form of initial socialization when the member has not been able to be independent. Meanwhile, another function is that family can be a medium for the members to grow and develop in accordance with their phases before reaching the independent stage and being ready to be released into the real world.

In relation to the function of media and parenting, then the family has a contribution the realization of which must really be observed. Parenting in children aims to regulate behavior, psychological development, motoric, and even the entire matters relating to child growth and development.

The development of children's intelligence is one aspect that describes parenting as what is carried out by their parents. Intelligence has sub-points such as the ability to deal with and adapt to a situation quickly and effectively, the ability to use and understand abstract concepts well, and the ability to understand relationships and learn them quickly. Intelligence is closely related to children's learning achievement. Learning achievement, which is basically influenced by several factors including internal factors originating in children, can be in the form of physical health. The next is external factors, which come from outside of the children's body, i.e. the family. The way that the family educates their children using parenting is different for each family. Moreover, family atmosphere also has some influence, and the last is the economic situation of the family. The third factor is the school factor. Schools, which are a medium for child growth, have their own share in the child development stages.

Parenting, especially, is so important in a family that when divided based on the parenting methods, parenting can be divided into three (3) as suggested by Baumrind (Mirsanti \& Warsiki 2010) which are authoritarian, democratic and permissive. Authoritarian parenting runs with parents as the ones who play the regulatory role. Children are required to comply and obey the rules made without any prior bargain. Disciplining with strict rules, restrictions and penalties cannot be separated from this pattern. Thus, it forms children's attitudes that are aggressive, disciplined, and dependent on parents. This is in contrast to the permissive pattern, which prioritizes freedom in children. Children are free to do anything without too binding restrictions. Parents give more confidence to children, so spoiled nature cannot be separated from the parenting. Therefore, children are formed with a high egoistical nature, who only know a few rules and difficult to control themselves. However, on the other hand, children become a brave person, and have a high level of confidence. The third parenting is democratic. As the name implies, parents who use this parenting method will try to provide restricted freedom to children. There are rules that have been agreed with the children so that the relationship between the both parents and children is well established. Parents play a role as the children's supporter and controller. Supervision of children of is not disregarded. Therefore, children can learn to be independent and make decisions responsibly. 
Oktaviana: The pattern of upbringing of middle to lower economic families in urban communities

\section{Method}

The method employed in this study is qualitative, so the data that is obtained is not in the form of figures and statistical calculations. This study utilized Verstehen's approach from Max Weber, which is by understanding and analyzing what is believed by the source without prejudice in it (Rahmawati 2016). The researchers do not share the contents of their mind in it and only act as observers. The researchers attempt to observe the social reality that occurs in the society and the social reasons in making a choice in social events. Referring to finding accurate data sources and relating to the selection of research sites, then, the selected research was carried out in Gubeng District Surabaya. For various reasons such as looking for sources of data in natural setting, the data produced was genuinely real and in accordance with the state of social reality.

\section{Determination of Informants}

Informants are the provider of data information in a study. Informants are the key the knowledge of whom will be dug on regarding the issues being examined. The determination the informants is adjusted to the object of research. If it relates to parenting, then it is possible to become an informant in accordance with the factors that have been discussed in the previous section, i.e. parents (family) and school. In connection with this, the informants in this study were restricted to teachers at the level of kindergarten and elementary school who are married and have children. Three informants have been selected with the same occupational background and the age range is 30-50 years. The three informants work in the world of education in the education community with lower middle economic class students.

\section{Data source}

The data obtained is divided into two, which are primary data and secondary data.

a. Primary data is the data obtained from the results of in-depth interviews and observations of objects as in the explanation of the point.

b. Secondary data is the data obtained from explorations of written sources, for example through literature studies and documentation studies. The increase in the literature study will be able to improve the understanding on the existing theories and adjust them with social reality. Therefore, there is more understanding on the relationship of cause-effect and the concept.

\section{Data collection process}

The data collection to support and seek the answers to the formulation of research problems is carried out through three ways or processes. The first was by utilizing in-depth interviews. Interviews with informants can be carried out to reap as much information as possible. The second was by performing observations on children who became the object of research. This observation is used to find out the magnitude of the level of reality and synchronization of data from informants and social conditions that occur. Finally, the third was the references. Information about relevant data can be obtained by reading many written sources in the references. The basic theories that have been put forward by experts are synergized with the results of existing research.

\section{Data analysis}

Data analysis is carried out to compile the existing data so that it is easier to understand, read and comprehend. Not the entire data obtained, however, could be used. That is why data sorting must be carried out to bring up a rough depiction of the results of the data set. After the data collected has been sorted, the conclusion can be drawn and analyzed further. The main data in this study, for example, was obtained by analyzing the parenting factors that lie behind parenting mistakes in children. 
Indonesian Journal of Social Sciences Volume 12 No. 01, January - June 2020, page 24-33

\section{The Research Result and Discussion}

\section{The first informant}

The first informant was a 49-year-old woman the background of whom was a school principal in one of the State Islamic Elementary Schools (Madrasah Ibtidaiyah) in Gubeng Airlangga area. Aside from being an educator, she cannot be separated from her role as a housewife with one husband and 2 children (a daughter and a son). The informant has been in the world of education for approximately 27 years and has been married for 23 years.

From the point of view of the informant, it can be explained that delinquency that occurs in children is increasing. This increase occurred because it was influenced by several factors, i.e. internal and external factors. The internal factors come from genetical things; thus, they are inborn traits. On the contrary, the external factors come from outside the children. These factors can be in the form of family, especially parents, school and social environment. When both factors are compared, external factors have a greater role and are far more complex than the internal ones.

In response to the importance of the role of external factors, schools as one part of these factors will not just sit there and do nothing. Schools must take some steps to prevent or overcome children delinquency. Teachers, principals, staffs, and other workers must take part in the realization of these steps. The steps taken by the school include the approach to children and families by incorporating PPK (Strengthening Character Education) sub-curriculum into the learning activities and in nonlearning activities as well. Schools prioritize character education in order to be able to be instill the attitudes that are ready to face challenges in the future to children through the inculcation of attitudes and characters in religion, independence, discipline and soft skills. In addition, schools can also use persuasive steps, which are performed by observation and direct approach to children. Children are asked to directly explain the problem.

Meanwhile, the approaching step to parents/guardians of students can be in the form of mediation efforts. Schools as the mediator must be perceptive and responsive. Parents can be requested to provide information about things that occur in the house and changes that may also be sensed by parents in their children. Parents also need to be able to see the development that occurs in their children.

Related to parenting, the greatest possibility to form good attitudes in children is to use democratic parenting. However, it is obvious that democratic patterns cannot necessarily be established since infancy. In regards to the children's independence and authority provision to make decisions personally, parents must become a fence so that children do not get out of the line. Especially for parents with the first child, they sometimes tend to be protective and unable to let go of their children. As a result, parenting becomes extreme and if parents are unable to control themselves, it will affect the growth and development of their children. For lower class families, permissive patterns tend to be used more. Parents feel that they have no time to supervise their children so that the freedom given is often misused by children.

Parents can give freedom to children to choose what they like. For example, in the matters relating to hobbies, children can have the freedom to prefer to play with pencils, books, dolls, and other games they like. The development of children's creativity and talent can be provoked with such things. In addition to giving freedom, parents can also find out the potentials that the children have, and the next step is to support the development of these potentials, for example, by putting children into the educational environment as early as possible. Parents must eliminate the dictator-authoritarian patterns by removing the use of the word "must" when asking children to do something, or the rules that are strict and inflexible for children. Parents must be responsive to the things that children do outside the house, such as their playing environment, and their social and friendship relationships. 
Oktaviana: The pattern of upbringing of middle to lower economic families in urban communities

\section{The second informant}

The second informant was a 30-year-old housewife who has a complete family with a son. Apart from being a housewife, the informant also became one of the teaching staffs at a tutoring institution. The informant has been in the education world for more or less around 9 years and has been married for 7 years.

The informant believes that the level of delinquency in children has admittedly increased. This is supported by several things including the development of technology that becomes the spectacle and reference for children, for example watching YouTube and other electronic media. This progress, however, is not compensated by the efforts to socialize knowledge of politeness and morality.

Nothing can hamper the rapid development of globalization. Thus, it is inevitable that we have to take a swim in the tide of globalization instead of being washed away in it. Here the role of parents is absolutely dominant. Children who are still in their development stage must be accompanied as a part of socialization or learning efforts. Parents can position themselves as their children's friend so that children do not need to feel reluctant and are able to the confidence to share everything that they experience and ask everything they want to know. That, however, does not mean that children do not obey their parents.

Children are ingrained with honesty from an early age because with honesty, parents can also control their children, for example by finding out what shows the child sees, what his heart desires, and other things that lead to his future. Therefore, parents can position their children in a place that is compatible with their interests and talents.

In terms of parenting, the appropriate one for the development of children towards the positive side is democratic parenting. With democratic parenting, children are more able to be independent and brave in making decisions without forgetting the impacts or consequences that arise from their decision making. Consequently, children can weigh up or calculate what kind of decisions to take. Parents still play a role as the observer and controller for their children. Hence, the existing limitations undoubtedly look clear and real but flexible. Nonetheless, the unfortunate thing is that parents today tend to prefer permissive parenting that is completely tolerant, spoiled, and far from independency. This mainly occurs in families where the mother and father of the child are workers. Childcare is left to other people who are paid. In contrast, in the lower middle-class families, the parents' education level of which is low, they will not be able to keep up with the times. As a result, the children become uncontrolled.

\section{The third informant}

The third informant was a kindergarten teacher with three children. The first child was a 23 -year-old son, the second child was a 17-year-old daughter and the last was an eight-year-old daughter.

Observing differences in the level of delinquency in today's children when compared with children in the past will result in very visible difference, especially in the attitudes. Children in the past really held the norms and regulations. However, it is tragic for children today who just do not know what the norms and regulations are. In terms of behavior, children's manner to their parents or the older people also fade over time.

School institutions that have a contribution in children's future must be prepared to respond to these issues. Schools can trace the reasons why children become delinquent. Schools can also take guidance steps for children after knowing the causes and problems being faced by children. Aside from guidance, parents and teachers can also work together to further approach the children. Therefore, the children will be controlled both inside and outside the house.

Early attitude inculcation must be implemented to become a provision for children to face the future. The main thing is by inculcating morals and religion. Children must understand, comprehend and apply moral attitudes as the key to behave. Moreover, religion can also act as the fence in acting and thinking. The implementation of this attitude inculcation activity can start with small things like habituation of 
reciting Asmaul Husna at the beginning of learning, praying in congregation, reciting (tadarus) AlQur'an.

The appropriate parenting to support the growth and development of children is the democratic parenting. Children basically have the same rights in the family in terms of regulatory agreements. Hence, it is suitable for children to develop what they are interested in and eager to do, but still under the control of the family. If in a family adopts inappropriate parenting, the school can take action by calling the parents to school and holding closed discussions so that parents can realize their mistakes. Parenting mistakes can cause setbacks in children. In addition, the impact is that children tend to do deviations as the chosen way out. As a comparison, liberal parenting will cause children to behave hyperactively, whereas in authoritarian parenting, children will act inferior and behave hard-headedly.

\section{Discussion}

The high level of teenage delinquency from year to year cannot be denied any longer as so much has changed from the system of parental control over their children. In the stage of growth and development, children need a model figure who will be an example for him. In this case, the closest characters to him are parents. According to a formula by Khoiruddin Nasution (Zaelani 2014), there are several rights that must be fulfilled by parents for their children. Among them are general rights in the form of guarantees of safety, and health as well as the right to a good name. The second is the rights during the nurturing period in the form of the right to life, subsistence right, and the right to moral, religious and cognitive education. The final right is post-parenting rights that include for example education/knowledge right, social right, personality right, good treatment right, and right to marry. These rights will then lead children in the stages of growth and development that allow them to have the capability of learning and pioneering themselves into qualified individuals. With guidance from parents, children who are in the learning process will be more controlled. Parents who play an important role must understand the condition and the psychological development of their children from time to time.

If reviewed according to Baumrind's theory (Mirsanti \& Warsiki 2010), in general, parenting mistakes that occur in the lower economic group take place because parents tend to use permissive parenting that is full of negligence. Children are neglected and feel excluded from their environment. In fact, it is very possible that children feel that they have to get out of their world and look for new things to replace the rights they do not get. Children will feel pressured because nobody else can accept them as a part of the family. Their existence is obscure and unappreciated. Children will find a new world that can make them comfortable. The egoism of parents that is high and always attaches more importance to their personal affairs makes children lose a role model figure in their life.

Mainly for the lower middle classes, in terms of the economy, these classes are financially disadvantaged. These economic limitations then cause new problems. Parents with low income who have high needs will feel depressed. Household problems will then develop into a vital problem in the family. Indonesia has people with various levels of social status. Parents who implement permissive parental type that is full of negligence tend to spend their time to find a way out of the valley of poverty since parents will feel pressured and depressed about the economic pressure they experience (Bahruddin 2013).

Lower-class parents who are too focused on finding the way out of poverty tend to forget their roles and duties as parents. Therefore, their children will be separated from parental control. Aggressive actions are carried out as the manifestation of their depression. Harmony in the family can be swayed because of this. In addition, if it is associated with harmony in family relationships, the level of marital satisfaction also contributes to the psychological development of children. The lower the level of marital satisfaction, the lower the level of family harmony is. Children who grow up in a harmonious family environment will experience hampered psychological development (Damariyanti 2015) because they often witness their parents quarrel before them, either because of economic problems or because 
Oktaviana: The pattern of upbringing of middle to lower economic families in urban communities

of other problems. However, with the low level of marital satisfaction, it is undeniable that once again, the environment contributes to the next stage in the psychological development of children. Children who experience the inappropriate parenting may experience several things, such as speech delay, psychological disorders, and other things that may be physically visible or psychologically. Children's delinquency can also be one of the resulted impacts, i.e. deviant behaviors as the children's escape way (Martini \& Angelika 2013).

On the other hand, the users of authoritarian parenting will shape a child's personality that is very different from permissive or democratic parenting. Students are educated strictly hard, full of rules and restraints. As a result, children have lack of confidence. The level of independence is also low because they always need help from their parents in deciding something. They are also very shy when in public (Rahmania \& Putra 2006).

Parents' failure to nurture their children has very big effects for children since their growth and development are not running normally, especially on the children's psychology. However, if reviewed one again, the most appropriate parenting is the democratic one because with this type of parenting, children will have more freedom in choosing their dreams and doing the things they like even though they are still not free from self-control and parents. Expressive is the attitude that children must develop to be able to get out of their zones and to explore everything they have, especially their potentials, both academically and non-academically. There is a low level of awareness among the lower-class community about the importance of improving the parenting of their children so far. By improving child parenting, it is very possible that the lower classes will be able to create quality individuals. Child parenting improvement is carried out in order to improve the integrity of the lower class both to get out of poverty and to improve their social stratum.

In addition to the social environment around the children's house, school environment is also able to support children to get out of the problem of parenting mistakes which will then form unfavorable and inappropriate personality. Schools also have many important roles for children. The readiness of schools to deal with children with diverse parenting makes schools must have a specific strategy. Schools can take steps to approach children. The approach must be balanced with in-depth observations to children related to every change and development they experience. Attitude inculcation towards children is also one of the roles of the school. Schools can include moral development materials in learning activities and non-learning activities, for example including the sub-materials like Strengthening Character Education (PPK). This effort aims to build the character of children into moral and virtuous individuals.

The approach taken is also to improve attitudes that reflect morality and religion. In religious terms, children can undergo activities such as reciting Asmaul Husna before the learning hours, reciting AlQur'an and taking prayers together for Muslims. With a religious approach, it is expected that schools will also be able to revive children's conscience from an early age. Therefore, their conscience does not die, so their morality can continue. Conscience has a very important role, especially the one related to the implementation of children's attitudes and character (Nashori 2004).

External and internal factors that are sensed by children that cause them to do deviant things must be immediately addressed by the school. Parents and teachers can work together and create synergy for both parties to observe the children's growth and development. Parents are not allowed to cover up the existing problems if the problem is related to the children's character growth and attitudes. Conversely, teachers should not just keep quiet when they know that there are inappropriate things for children. With mutual reciprocity, it is guaranteed that children will be well controlled and can stay away from deviant behaviors (Wulaningsih \& Hartini 2015).

Therefore, in comparison of the types of parenting, the most appropriate way to direct children to become good individuals is to use democratic parenting. Children can grow up with restricted freedom. They can be an independent individual and are responsible for all the decisions they make. Children 
Indonesian Journal of Social Sciences Volume 12 No. 01, January - June 2020, page 24-33

can also position themselves according to different circumstances. Control from the family and the environment will allow children to overcome the effects of certain behavior. Children are able to develop themselves to achieve their dreams without coercion from outside. Their interests and talents can be channeled properly. The characters that appear in children are of high quality. Not all children are able to hone themselves well. That is why the synergy of the environment, parents and schools is very vital for children. In addition, children will have the freedom to choose what they want from a lesson and even which method they use to learn. Children can feel comfortable with the teacher because the teacher not only acts as an information center, but also can position himself as a friend. Friend in this case is to become the source of information and a moderator without eliminating the norms of politeness and courtesy given that teachers are a role model who is of higher age and strata. Consequently, children can be expected to be individuals who are able to actualize themselves according to their potential.

\section{Conclusion}

The fruit does not fall far from the tree. This saying is in harmony with the subject discussed in this article. With the appropriate parenting, children will develop well. Psychologically, children need their parents or closest people to be a model in learning. In the lower-class environment, psychological problems are not put in the spotlight because of lack of awareness of the parenting role in the development of the children's personality. One of the factors that influences lower-class families in providing appropriate parenting starts from financial incapacity which makes them neglect children's psychological growth even though it can be in resolved with social capital. This is different from the level of marital satisfaction that can actually be resolved by the process of forgiveness and psychological well-being (Damariyanti 2015). External environment can also support children's revival from parenting mistakes in the family. External environment can be the school environment. Children will be able to learn together with their peer friends which can be the medium to observe whether the children's development is disrupted. Schools can have the synergy to work together with parents to regulate, observe and take steps to prevent and cope with children's deviant behaviors. Attitude inculcation from an early age can foster the children's character into a good person in order to face challenges in the future. The most appropriate parenting style for children is democratic parenting. Children can develop their talents and interests freely, but still under the control of parents and school. Restricted freedom will teach children many things in developing good self-characters.

\section{References}

Bahruddin R (2013) Hubungan Kondisi Ekonomi Orang Tua Dengan Pola Asuh Anak Pada Paud Terpadu Upt Skb Bantul Kab. Bantul. Skripsi, Universitas Negeri Yogyakarta, Yogyakarta.

Damariyanti M (2015) Pengaruh Kesejahteraan Psikologis Dan Pemaafan Terhadap Kepuasan Penikahan. Jurnal Psikologi 8 (2): 104-111.

Haryono TJS (2012) Pengantar Antropologi. Surabaya: Revka Petra.

Martini AW \& Angelika D (2013) Studi Tentang Pola Asuh terhadap Gangguan Perkembangan Anak. :1-7. http://journal.unair.ac.id/download-fullpapers-msj52ad8e38f5full.pdf.

Mirsanti D \& Warsiki E (2010) Berbagai Jenis Pola Asuh Orang Tua Dan Pengaruh Pola Asuh. :1-11. http://journal.unair.ac.id/download-fullpapers-psikiatri983528979b2full.pdf.

Nashori F (2004) Menjadi Manusia Kreatif: Ketua Umum Asosiasi Psikologi Islami. Humanitas: Jurnal Psikologi Indonesia 1 (1): 1-5.

Rahmania HN \& Putra MGBA (2006) Hubungan antara Persepsi terhadap Pola Asuh Otoriter Orang Tua dengan Kecenderungan Pemalu (Shyness) pada Remaja Awal. INSAN 8 (3): 211 - 219.

Rahmawati F (2016) Pola asuh keluarga bercerai dalam membentuk perilaku anak. Disertasi, Universitas Airlangga, Surabaya.

Rahmayanti KA (2011) Hubungan sikap ibu tentang asi eksklusif dengan perilaku pemberian asi 
Oktaviana: The pattern of upbringing of middle to lower economic families in urban communities

eksklusif di desa sendangrejo kecamatan tayu kabupaten pati. [Diakses 2 Desember 2017]. http://digilib.unimus.ac.id/files/disk1/121/jtptunimus-gdl-kikaaldela-6006-3-babiii.pdf.

Wulaningsih R \& Hartini N (2015) Hubungan antara Persepsi Pola Asuh Orangtua dan Kontrol Diri Remaja terhadap Perilaku Merokok di Pondok Pesantren. Jurnal Psikologi Klinis dan Kesehatan Mental 4 (2): 119-126.

Zaelani AQ (2014) Pola Asuh Anak Dalam Perspektif Yuridis Dan Psikologi Pendidikan. ASAS Jurnal Hukum Ekonomi Syari’Ah 6 (2): 29-37. 